\title{
Schmallenberg virus: continuing a trend?
}

\author{
This article was published in the following Dove Press journal: \\ Virus Adaptation and Treatment \\ 24 April 2013 \\ Number of times this article has been viewed
}

\section{Rob Noad Joe Brownlie \\ Department of Pathology and Pathogen Biology, Royal Veterinary College, Hatfield, UK}

Correspondence: Rob Noad

Centre for Emerging Endemic and Exotic Diseases, Royal Veterinary College,

Hawkshead Lane, Hatfield AL9 7TA

United Kingdom

Tel +440I7076 67062

Fax +440I7076 670 5I

Email rnoad@rvc.ac.uk

\begin{abstract}
Since its first isolation in Germany in 2011 the Schmallenberg strain of the Sathuperi virus has been detected across northern Europe. The virus is associated with neurological disease, abortion, and congenital deformities in ruminants, particularly among sheep and cattle. The rapid dissemination of the pathogen is reminiscent of the transmission of another midge-borne arbovirus, Bluetongue virus, which also spread to Europe on several separate occasions between 1998 and 2007. In this review we detail the characteristic features of the Schmallenberg virus and consider whether the virus highlights a European vulnerability for other midge-transmitted pathogens.
\end{abstract}

Keywords: Schmallenberg, Sathuperi, Culicoides, bunyavirus, midge, bluetongue

\section{Schmallenberg virus: virus isolation and related viruses}

Schmallenberg virus was first identified by next generation sequencing of complementary deoxyribonucleic acid (cDNA) prepared from the plasma of cattle with fever and reduced milk yield near Schmallenberg in Germany in November 2011. ${ }^{1}$ Cattle with similar clinical signs were also reported at the same time in the Netherlands. Reverse transcription-polymerase chain reaction (RT-PCR)-based tests were developed, and testing of archive samples revealed no evidence for the presence of the virus before 2011. ${ }^{2}$ From December 2011, Schmallenberg virus was associated with an epizootic of deformed calves and lambs across Europe with cases in France, Germany, Belgium, The Netherlands, the United Kingdom, Switzerland, Luxembourg, Italy, Denmark, and Spain..$^{2}$ Initial sequence analysis placed Schmallenberg virus as a novel virus in the Simbu serogroup of the genus Orthobunyavirus in the family Bunyaviridae. ${ }^{1,3}$ More recent sequencing analysis places the Schmallenberg virus within the species of the Sathuperi virus. ${ }^{4}$

The Simbu serogroup contains 25 viral species and is one of the largest serogroups within the Orthobunyavirus genus..$^{5-8}$ Other viruses in the serogroup include the human pathogen Oropouche virus, which is mosquito-transmitted and causes a nonfatal dengue fever-like illness in the Caribbean and in South America, and Akabane virus, which causes epizootic congenital malformations in ruminants (Table 1). Phylogenetically, Sathuperi virus is the most closely related to Shamonda, Akabane, and Aino viruses, which are all transmitted by midges of the Culicoides genus and also cause disease in ruminants. ${ }^{4,8}$ Although insect transmission studies with Schmallenberg virus have not yet been reported, the virus has been detected by RT-PCR from pools of Culicoides midges within affected areas. ${ }^{9-11}$ Sathuperi virus has also been reported 


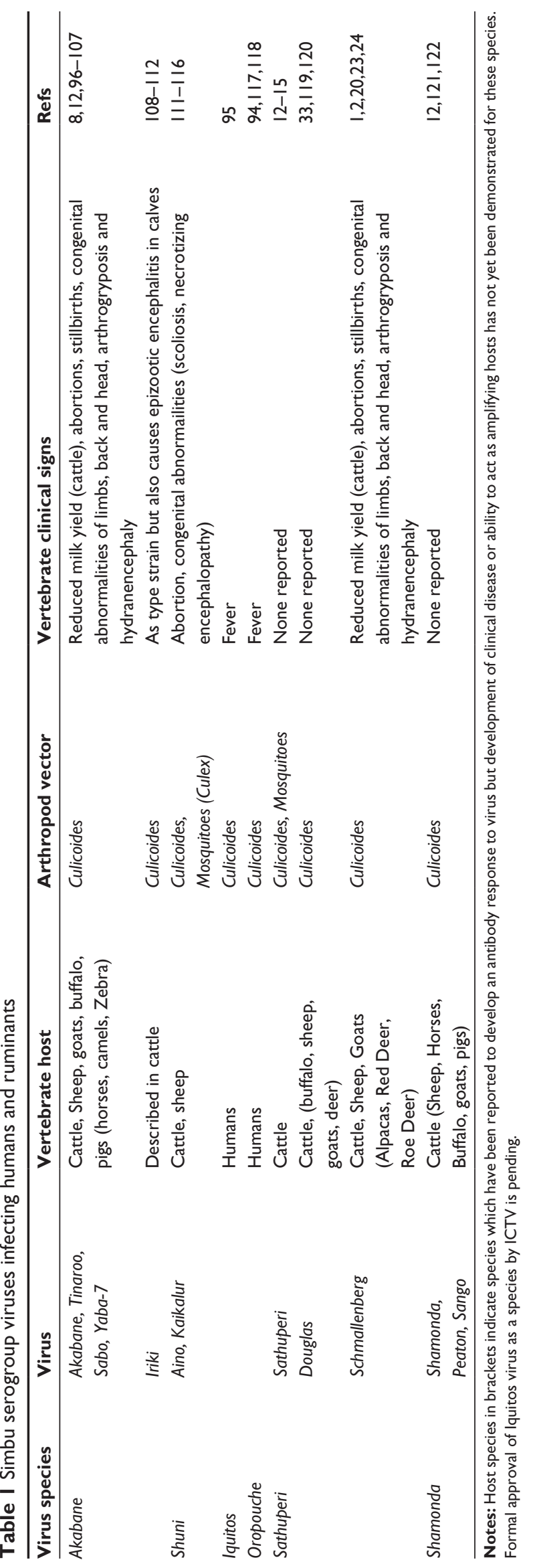

to be transmitted by midges in Nigeria and Japan. ${ }^{12-14}$ Since Sathuperi virus was originally isolated from Culex spp. mosquitoes in the Andhra Pradesh and the Tamil Nadu region in India, ${ }^{15}$ the role of other arthropods, particularly mosquitoes, in the transmission of Schmallenberg virus cannot be ruled out. However, given the repeated isolation of Schmallenberg or Sathuperi viruses from Culicoides spp. midges in Europe, ${ }^{9-11}$ Japan, ${ }^{3,14}$ and Nigeria, ${ }^{13}$ it is likely that they are also the major vector for Schmallenberg virus in Europe.

\section{Clinical signs}

As with most viruses that can replicate in multiple hosts, disease pathology of Schmallenberg virus is dependent on the infected species. Experimental infection of type 1 interferon knockout mice and cattle with Schmallenberg virus have both been reported. ${ }^{1,16,17}$ In the first cattle study, three 9-month-old calves were inoculated with the virus; one calf developed fever $\left(40.5^{\circ} \mathrm{C}\right)$ and one had mucous diarrhea. ${ }^{1}$ In this study, viral ribonucleic acid (RNA) was detected by RT-PCR for $2-5$ days postinoculation. ${ }^{1}$ In the second study, eight 9-18-month-old calves were inoculated with serum from an experimentally infected animal that showed clinical signs (four animals), or $2 \times 10^{7} \mathrm{TCID}_{50}$ virus that had been passaged no more than four times in cell culture (four animals). Although no animal developed detectable fever, and only one animal developed mild diarrhea, all virus-inoculated animals developed viraemia detectable for 5-7 days by real time RT-PCR, and all seroconverted by enzyme-linked immunosorbent assay (ELISA) by day 21 postinoculation. ${ }^{17}$ Four in-contact control animals that were not inoculated with the virus developed neither detectable nor seroconverted viraemia.

Although Schmallenberg virus was originally associated with reduced milk yield and diarrhea in adult cattle, its main clinical impact has been related to teratological effects when pregnant sheep, cattle, and goats have been infected with the virus. Affected fetuses often spontaneously abort and can display arthrogryposis, as well as malformations of the skull, spinal column, and brain including macrocephaly, kyphosis, scoliosis, torticollis, lordosis, cerebellar hypoplasia, hydrocephalus, and porencephaly. ${ }^{18-21}$ Fetuses that go to full term can display a range of clinical signs ranging from malformations similar to aborted fetuses to morphologically normal animals with neurological signs such as ataxia, blindness, paralysis, exaggerated movements, and polioencephalomyelitis. ${ }^{20,22}$ For wild ruminants, there is evidence that both red deer and roe deer have been exposed 
to Schmallenberg virus and develop an antibody response. ${ }^{23}$ However, in this study, there was no evidence for viral RNA in deer or epizootics of congenital malformations. There is also evidence that alpacas kept in areas where Schmallenberg virus is circulating tend to develop an antibody response to the virus, ${ }^{24}$ although, to our knowledge, no confirmed cases of clinical disease have been reported in alpacas or other camelids.

The clinical signs of Schmallenberg virus infection in sheep, cattle, and goats are consistent with those described for other related Simbu serogroup viruses that infect ruminants, particularly Akabane virus and Aino virus. ${ }^{21,25-30}$ However, some clinical signs reported for Akabane, such as epizootic encephalomyelitis, ${ }^{31}$ have not yet been reported for Schmallenberg virus. Relatively little description of clinical disease has been reported for Sathuperi virus. The virus was first isolated in India in 1955-1957, ${ }^{15}$ and it was then detected in Nigeria from the mid-1960s. ${ }^{12,13}$ The next report of Sathuperi virus isolation was from Japan in 1999. ${ }^{3}$ Intriguingly, none of these prior isolations coincided with epizootic outbreaks, nor were clinical signs reported from the source animals. Douglas virus, isolated in Australia, is another isolate within the Sathuperi virus species. ${ }^{4,32,33}$ Although there is a lack of description of clinical disease for Douglas virus in ruminants, there is a report comparing the teratogenic potential of Akabane and Douglas viruses in an embryonated egg model system. ${ }^{34}$ In this system, Akabane infections led to clinical signs in chicks similar to those seen when the same virus infects ruminants in utero (arthrogryposis in the legs and feet, scoliosis, and retarded development). For Akabane disease, clinical signs were noted from doses of 8-300 pfu/egg, depending on the strain. In contrast, the Douglas virus only induced similar clinical signs when doses of $1.4 \times 10^{5}$ pfu per egg were used. ${ }^{34}$

At this stage, it is unclear why Schmallenberg virus appears to be much more pathogenic than its closest genetic relatives, Sathuperi and Douglas viruses. ${ }^{4}$ It may simply be a case of a new virus spreading into a naïve population and resulting in rapid amplification and dissemination of the pathogen. Certainly, there is evidence that the transport of pregnant cattle to Akabane-endemic areas followed by the returning of these cattle to "naïve" areas can result in significant disease outbreaks. ${ }^{35}$ An alternative possibility is that amino acid changes in Schmallenberg virus from the parental Sathuperi virus have rendered it more pathogenic in ruminants.

\section{Molecular biology}

Although Schmallenberg virus has only been recently described, the Orthobunyavirus genus is one of the best studied genera within the Bunyaviridae family in terms of its molecular biology. Orthobunyaviruses have a tripartite negative-sense single stranded RNA genome (Figure 1A). The three genome segments are designated as $\mathrm{L}$, which encodes the viral RNA-dependent RNA polymerase; M, which encodes the viral glycoproteins Gn and Gc and the nonstructural protein NSm; and S, which encodes the nucleocapsid protein, $\mathrm{N}$, and nonstructural protein, NSs.

As a consequence of the segmented nature of the genome, bunyaviruses that share common replication and packaging signals are able to reassort segments when coinfecting the same host. Indeed, based on partial sequence data, Schmallenberg virus was proposed to be a reassortant between Shamonda and Sathuperi viruses. ${ }^{3}$ More recent sequencing data suggest that it is Shamonda virus that is a reassortant between Schmallenberg virus and a third, uncharacterized orthobunyavirus. ${ }^{4}$ Shamonda virus, has L and $\mathrm{S}$ segments that have high levels of sequence similarity to Schmallenberg virus, but the M segment of Shamonda virus is only distantly related to the M segment of Schmallenberg virus. ${ }^{4}$ If this is correct, the Schmallenberg virus parent of

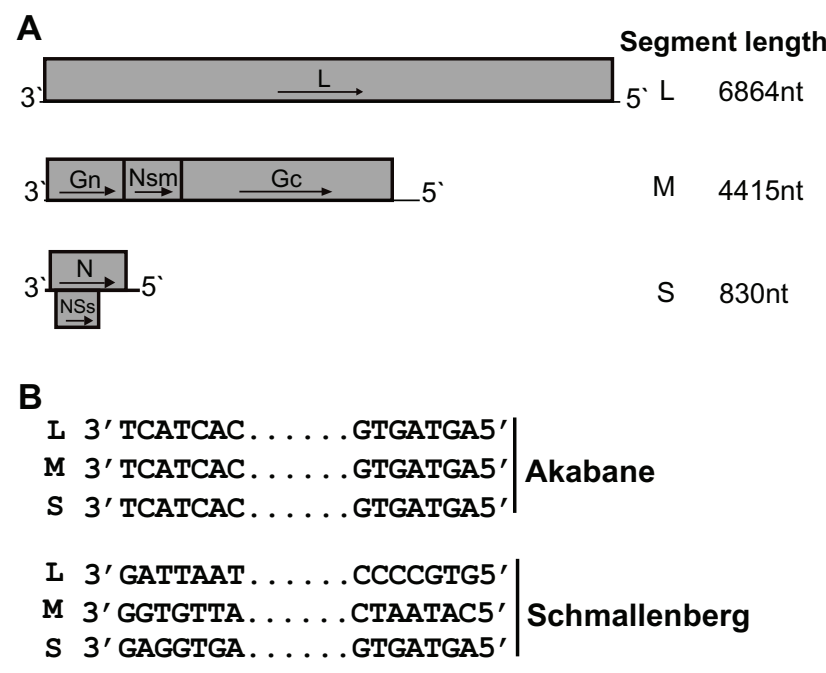

Figure I Genome organization of the Schmallenberg virus. (A) The virus has three strands of negative-sense single stranded RNA (L, M, and S). L encodes the multifunctional cap endonuclease-RNA-dependent-RNA-polymerase enzyme; $M$ encodes two glycoproteins, $\mathrm{Gn}$ and $\mathrm{Gc}$, and the nonstructural protein, NSm, encoded as a polyprotein; $\mathrm{S}$ encodes the nucleocapsid $(\mathrm{N})$ and, from an alternative frame-shifted start codon, the nonstructural protein, NSs. All three genome segments must be transcribed to positive sense RNA before translation is possible. Arrows indicate the direction of translation. (B) The genome terminal nucleotides of the three segments of the Akabane virus and Schmallenberg virus.

Notes: Like other bunyaviruses, the terminal sequences of Akabane are conserved between segments and are complementary. Current sequences for the Schmallenberg virus do not match this pattern.

Abbreviations: RNA, ribonucleic acid; L, large; M, medium; S, small. 
Shamonda virus must have been circulating in the field since before 1965, when Shamonda virus was isolated from cattle in Nigeria. ${ }^{8,12}$

Consistent with its original identification by next generation sequencing, the full genome sequence of all three segments of Schmallenberg virus have been published. ${ }^{1}$ However, one of the features of bunyavirus genomes is that segments share conserved, complimentary terminal nucleotides at the $5^{\prime}$ and $3^{\prime}$ ends of the RNA segments. ${ }^{5,36-39}$ Each of the published terminal sequences for the Schmallenberg viral segments is different (Figure 1B), so it is likely that these sequences are either missing or extended nucleotides. Indeed, in order to recover the replicating Schmallenberg virus from cloned cDNA, Elliott et $\mathrm{al}^{40}$ found it necessary to modify the published sequences to include terminal nucleotides predicted from a consensus of other Simbu serogroup viruses. The modified Schmallenberg virus had similar growth in cell culture to the original, unmodified isolate, which was recovered in baby hamster kidney (BHK21) cells after prior incubation (10 days) of sonicated blood with a Culicoides (KC) cell line. ${ }^{1,40}$

Bunyaviruses replicate in the cytoplasm of infected cells and assemble in the lumen of Golgi stacks. ${ }^{41-45}$ The viral glycoproteins, Gn and Gc, and the nonstructural protein, NSm, are encoded by the mRNA segment. Gn and Gc form a heterodimer that is retained in the Golgi to allow virus assembly. ${ }^{46-50}$

There is evidence for functional interactions between the $5^{\prime}$ and $3^{\prime}$ end of the negative sense viral genomic RNA segments and for the direct interaction between these and the viral nucleocapsid, N, and the RNA-dependent-RNA polymerase, L. ${ }^{5,45}$ Transcription occurs in the cytoplasm and involves priming of viral transcripts using short, capped oligonucleotides derived from cellular mRNAs. ${ }^{51-55}$ To enable this cap-snatching mechanism, which is analogous to that employed in the nucleus by Influenza A virus, the bunyavirus $\mathrm{L}$ proteins have cap-dependent endonuclease activity. ${ }^{53,56}$
Although there is no direct evidence for this endonuclease activity for the Schmallenberg virus L, the protein does contain the conserved motifs associated with this activity in other bunyaviruses (Figure 2). Although bunyavirus transcripts are not polyadenylated, there is evidence from several members of the Bunyaviridae family that the untranslated regions of several bunyaviruses contain cis-acting sequences that promote efficient translation of the viral messenger-sense RNA in the absence of a poly-A tail. ${ }^{57-60}$

In mammalian cells, but not in vector insect cells, replication of some bunyaviruses, including Schmallenberg virus, results in the shut off of host cell transcription. ${ }^{40,61-66}$ This effect is mediated by the viral NSs protein and was initially characterized as a way in which bunyaviruses avoid interferon and other antiviral responses that require transcription. Although not all bunyaviruses encode a NSs ortholog, ${ }^{45,67}$ Schmallenberg virus does. Furthermore, the recovery of a Schmallenberg virus variant in which NSs is deleted resulted in a virus with reduced ability to shut down host cell transcription and increased induction of interferon synthesis in infected mammalian cells. ${ }^{40}$

\section{Spread}

With relatively little data on the basic biology of Schmallenberg virus, beyond what can be inferred from the replication of other orthobunyaviruses, there have been several recent reviews that have focused on the identification and spread of the virus. ${ }^{2,19,20,68}$ Rather than repeat the detailed epidemiological situation, which has been well covered by others, we will limit our discussion to the key features of the European Schmallenberg virus outbreak. Firstly, the detection of the virus in 2011 appears to genuinely coincide with the introduction of Schmallenberg virus into Europe. Testing of retrospective samples has consistently failed to identify any cases that are positive by PCR or ELISA prior to 2011.1,2 Despite the intriguing hints from the similarity between Schmallenberg virus and two of the three segments of Shamonda virus noted

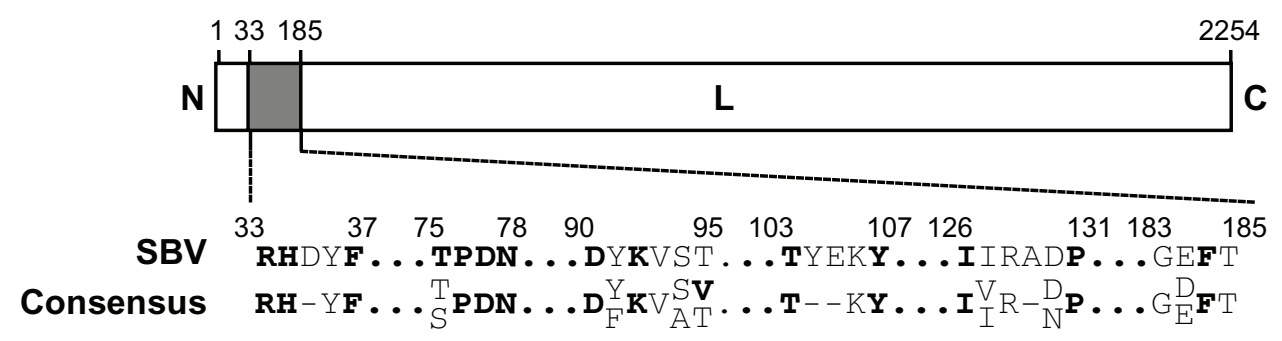

Figure 2 Position and sequence of the putative cap-snatching endonuclease in Schmallenberg virus L.

Notes: The position of the putative cap-snatching endonuclease and sequence motifs in Schmallenberg $L$ are indicated. Amino acids in bold in this motif have been characterized as important for nuclease function in the La Crosse virus. ${ }^{56}$ The consensus sequence shows the variation in these sequences across the $L$ protein of 35 other orthobunyavirus isolates. 
above, neither the original source of the Schmallenberg virus outbreak, nor the field circulation of the Schmallenberg virus strain outside Europe have been reported.

Secondly, spread of Schallenberg virus has been extremely rapid. This is consistent with the spread of the Bluetongue virus in northern Europe in 2006-2009. ${ }^{69-71}$ If anything, the spread of Schmallenberg virus has been even more rapid, and involves rapid spread even against the direction of the prevailing winds in this region. It is probably worth noting that in controlled infection studies in paleoarctic species of Culicoides in which Bluetongue virus was fed to midges, only $0.4 \%-7.4 \%$ of midges were susceptible to infection. ${ }^{72}$ Therefore, the increased spread of Schmallenberg virus may simply be a result of more efficient uptake into the vector. Interestingly, the time of year with peaks of animals testing positive for Schmallenberg virus are consistent with those testing positive for Bluetongue virus in the recent Bluetongue virus type 8 outbreak, which further supports the hypothesis that Schmallenberg disease is primarily midge transmitted. ${ }^{2}$ However, at this stage, it is not possible to rule out the possibility that other blood feeding arthropods may play a role in transmission of the virus.

Finally, the Schmallenberg outbreak is ongoing, with continued seroconversion of animals in the past year. ${ }^{23,73-83}$ Surveys of immune responses among the camelids and ruminants at the Royal Veterinary College, London to the Schmallenberg virus have suggested that although only 3\% of ruminants were seropositive in July 2012, whilst 62\% had been seroconverted by November 2012 (Brownlie et al, personal communication). ${ }^{24}$ The clinical implications and reproductive consequences of this are being studied further.

\section{Future control measures}

The degree of control necessary for Schmallenberg virus is currently unclear. The lack of clinical disease in other parts of the world - despite evidence from molecular reassortment studies that the virus has been present for some time, ${ }^{4,12}$ and the evidence that prior infection provides protection from reinfection ${ }^{2}$ - suggests that herd immunity may be one of the biggest factors in controlling the impact of this disease. It may be possible to manipulate this by vaccination, although currently no licensed vaccines are available. Inactivated and attenuated virus vaccines have been shown to be effective for other Simbu serogroup viruses. ${ }^{84-86}$ It is also likely that the Schmallenberg virus NSs knockout mutant viruses could be the basis for an effective vaccine. ${ }^{40,87}$ Clone 13 , a naturally occurring NSs deletion mutant of the Rift Valley fever virus has been demonstrated to be an effective vaccine candidate in sheep and cattle. ${ }^{88,89}$ However, clone 13 contains a large deletion in NSs, which is possible because the nucleocapsid (N) and NSs genes are coded separately and in opposite directions on the S segment of the Rift Valley fever virus RNA. In Schmallenberg virus and other orthobunyaviruses, $\mathrm{N}$ and NSs overlap and are encoded by different initiation sites (start codons) in the same viral strand (Figure 1A). Therefore, although it is possible to knock out NSs expression through the insertion of stop codons or via mutation of ATG codons, it is not possible to delete this gene without also deleting the coding sequence for the essential protein, N. Schmallenberg virus NSs knockout mutants may, therefore, have more potential to revert than NSs deletion mutants for other bunyaviruses. This may be a serious concern for developing these mutants as potential vaccine candidates. As with all viruses with segmented genomes, there is a further complication that attenuated live virus vaccines may reassort with circulating field strains of the virus.

Control of bunyaviruses through the control of Culicoides midges seems unlikely to be effective; the midges are $<3 \mathrm{~mm}$ long, thus effective insect proof screening on livestock housing is impractical under field conditions. Furthermore, even cattle dung from inside cattle housing can provide sufficient moisture for the midge to go through its larval stages. ${ }^{90,91}$ Insecticides and repellants could have some potential, but the elimination of biting in the field, or potential cervid hosts, would not be affected by these controls. Similarly, controls on the movements of affected livestock are impacted by the fact that Culicoides midges can be blown by wind for hundreds of kilometers. ${ }^{92}$ Indeed, the recent finding that wind dispersal of Culicoides appears to be the most significant factor in the 2006-2009 outbreak of Bluetongue virus (another Culicoides-transmitted viral disease), it may also have relevance in the spread of Schmallenberg virus. ${ }^{93}$

In common with the earlier Bluetongue virus outbreaks, the cold winters in northern Europe do not appear to have been a barrier to the overwintering of Schmallenberg virus. Whether this is because the virus is maintained in developing fetuses over winter - which can then become the foci for new infections in the spring if they survive - or whether it overwinters by some other mechanism, such as transovarial transmission in Culicoides or in alternative long-lived arthropods such as ticks, is currently unclear.

The long-term potential for controlling Schmallenberg virus will be dependent on the degree to which the virus can persist in wild ruminants and the availability of suitable vaccines. Eradication in Europe is a theoretical possibility if vaccines were available, but this would require a coordinated 
vaccination program across all affected countries due to the rapid spread of the disease from affected areas. Whether vaccination is economically justified will depend on the impact the disease has on the production costs of European farmers, which have not yet been quantified.

\section{Other threats}

Although at this stage the long-term economic significance of Schmallenberg disease is unclear, the outbreak does highlight the potential of exotic arboviral diseases to spread rapidly into new areas. It is possible that outbreaks of two Culicoides midge-transmitted pathogens (Bluetongue virus and Schmallenberg virus) occurring within 6 years of each other is a coincidence; however, in the context of the separate and repeated incursions of bluetongue into southern Europe in the 8 years prior to that, ${ }^{70}$ it seems more likely that conditions in Europe now favor the transmission of previously exotic midge-transmitted viral diseases.

Fortunately, relatively few zoonotic diseases are transmitted by midges and those that are, such as Oropouche and Iquitos, ${ }^{94,95}$ do not generally result in life-threatening illnesses. Of the animal pathogens, Bluetongue virus, African horse sickness virus, as well as the Akabane and Aino viruses are among the most significant in other parts of the world. For the Bluetongue virus and African horse sickness virus, both viruses exist as multiple serotypes, which do not confer cross-protection. Therefore, animals currently vaccinated against Bluetongue virus-11, Bluetongue virus-4, or Bluetongue virus-8 would not be protected from infection with any of the other 23 serotypes of Bluetongue virus in a future outbreak. Similarly, antibodies raised to Schmallenberg virus do not efficiently cross-neutralize some other Simbu group viruses, such as Shamonda or Sabo viruses. ${ }^{4}$

\section{Summary}

Since its initial identification by next-generation sequencing, Schmallenberg virus has spread rapidly through European domestic ruminants, causing an epizootic of congenital abnormalities. Current data suggest that the virus is a member of the species Sathuperi virus, although the severity of the clinical signs reported for Schmallenberg virus exceeds any previous Sathuperi outbreak. Controls put in place following the bluetongue epizootic in northern Europe in 2006-2009 have been largely ineffective at controlling the spread of Schmallenberg virus infections. The most effective future controls, if necessary on welfare or economic grounds, are likely to be dependent on the development and use of effective vaccines, which are a realistic possibility for this virus. It is likely that outbreaks of other midge-transmitted diseases will occur in Europe in the future, and they will be similarly resistant to controls. Therefore, the development of safe, effective vaccines to these pathogens should be prioritized.

\section{Disclosure}

The authors report no conflicts of interest in this work.

\section{References}

1. Hoffmann B, Scheuch M, Höper D, et al. Novel orthobunyavirus in Cattle, Europe, 2011. Emerg Infect Dis. 2012;18(3):469-472.

2. Beer M, Conraths FJ, van der Poel WH. 'Schmallenberg virus' - a novel orthobunyavirus emerging in Europe. Epidemiol Infect. 2013;141(1): $1-8$.

3. Yanase T, Kato T, Aizawa M, et al. Genetic reassortment between Sathuperi and Shamonda viruses of the genus Orthobunyavirus in nature: implications for their genetic relationship to Schmallenberg virus. Arch Virol. 2012;157(8):1611-1616.

4. Goller KV, Höper D, Schirrmeier H, Mettenleiter TC, Beer M. Schmallenberg virus as possible ancestor of Shamonda virus. Emerg Infect Dis. 2012;18(10):1644-1646.

5. Elliott RM. Molecular biology of the Bunyaviridae. J Gen Virol. 1990; 71(Pt 3):501-522.

6. Kinney RM, Calisher CH. Antigenic relationships among Simbu serogroup (Bunyaviridae) viruses. Am J Trop Med Hyg. 1981;30(6): 1307-1318.

7. Shope RE. Bunyaviruses. In: Baron S, editor. Medical Microbiology, 4th ed. Galveston, TX: University of Texas Medical Branch at Galveston; 1996.

8. Saeed MF, Li L, Wang H, Weaver SC, Barrett AD. Phylogeny of the Simbu serogroup of the genus Bunyavirus. J Gen Virol. 2001;82(Pt 9): 2173-2181.

9. De Regge N, Deblauwe I, De Deken R, et al. Detection of Schmallenberg virus in different Culicoides spp. by real-time RT-PCR. Transbound Emerg Dis. 2012;59(6):471-475.

10. Elbers AR, Meiswinkel R, van Weezep E, van OldruitenborghOosterbaan MM, Kooi EA. Schmallenberg virus in Culicoides spp. biting midges, The Netherlands, 2011. Emerg Infect Dis. 2013; 19(1):106-109.

11. Rasmussen LD, Kristensen B, Kirkeby C, et al. Culicoids as vectors of Schmallenberg virus. Emerg Infect Dis. Jul 2012;18(7): 1204-1206.

12. Causey OR, Kemp GE, Causey CE, Lee VH. Isolations of Simbu-group viruses in Ibadan, Nigeria 1964-1969, including the new types Sango, Shamonda, Sabo and Shuni. Ann Trop Med Parasitol. 1972;66(3): 357-362.

13. Lee VH. Isolation of viruses from field populations of culicoides (Diptera: Ceratopogonidae) in Nigeria. J Med Entomol. 1979;16(1):76-79.

14. Yanase T, Fukutomi T, Yoshida K, et al. The emergence in Japan of Sathuperi virus, a tropical Simbu serogroup virus of the genus Orthobunyavirus. Arch Virol. 2004;149(5):1007-1013.

15. Dandawate CN, Rajagopalan PK, Pavri KM, Work TH. Virus isolations from mosquitoes collected in North Arcot district, Madras state, and Chittoor district, Andhra Pradesh between November 1955 and October 1957. Indian J Med Res. 1969;57(8):1420-1426.

16. Wernike K, Breithaupt A, Keller M, Hoffmann B, Beer M, Eschbaumer M. Schmallenberg virus infection of adult type I interferon receptor knock-out mice. PLoS One. 2012;7(7):e40380.

17. Wernike K, Eschbaumer M, Breithaupt A, Hoffmann B, Beer M. Schmallenberg virus challenge models in cattle: infectious serum or culture-grown virus? Vet Res. 2012;43(1):84.

18. van den Brom R, Luttikholt SJ, Lievaart-Peterson K, et al. Epizootic of ovine congenital malformations associated with Schmallenberg virus infection. Tijdschr Diergeneeskd. 2012;137(2):106-111. 
19. Conraths F, Peters M, Beer M. Schmallenberg virus, a novel orthobunyavirus infection in ruminants in Europe: potential global impact and preventive measures. $N$ Z Vet J. 2012;61(2):63-67.

20. Garigliany MM, Bayrou C, Kleijnen D, et al. Schmallenberg virus: a new Shamonda/Sathuperi-like virus on the rise in Europe. Antiviral Res. 2012;95(2):82-87.

21. Herder V, Wohlsein P, Peters M, Hansmann F, Baumgärtner W. Salient lesions in domestic ruminants infected with the emerging so-called Schmallenberg virus in Germany. Vet Pathol. 2012;49(4):588-591.

22. Peperkamp K, Dijkman R, van Maanen C, et al. Polioencephalo-myelitis in a calf due to infection with Schmallenberg virus. Vet Rec. 2012;170(22):570

23. Linden A, Desmecht D, Volpe R, et al. Epizootic spread of Schmallenberg virus among wild cervids, Belgium, Fall 2011. Emerg Infect Dis. 2012;18(12):2006-2008.

24. Jack C, Anstaett O, Adams J, Noad R, Brownlie J, Mertens P. Evidence of seroconversion to SBV in camelids. Vet Rec. 2012;170(23):603.

25. Charles JA. Akabane virus. Vet Clin North Am Food Anim Pract. 1994;10(3):525-546.

26. Hashiguchi Y, Nanba K, Kumagai T. Congenital abnormalities in newborn lambs following Akabane virus infection in pregnant ewes. Natl Inst Anim Health Q (Tokyo). 1979;19(1-2):1-11.

27. Kessell A, Finnie J, Windsor P. Neurological diseases of ruminant livestock in Australia. IV: viral infections. Aust Vet J. 2011;89(9): 331-337.

28. Kirkland PD, Barry RD, Harper PA, Zelski RZ. The development of Akabane virus-induced congenital abnormalities in cattle. Vet Rec. 1988;122(24):582-586.

29. Narita M, Inui S, Hashiguchi Y. The pathogenesis of congenital encephalopathies in sheep experimentally induced by Akabane virus. J Comp Pathol. 1979;89(2):229-240.

30. Tsuda T, Yoshida K, Ohashi S, et al. Arthrogryposis, hydranencephaly and cerebellar hypoplasia syndrome in neonatal calves resulting from intrauterine infection with Aino virus. Vet Res. 2004;35(5): 531-538.

31. Kono R, Hirata M, Kaji M, et al. Bovine epizootic encephalomyelitis caused by Akabane virus in southern Japan. BMC Vet Res. 2008;4:20.

32. St George TD, Cybinski DH, Filippich C, Carley JG. The isolation of three Simbu group viruses new to Australia. Aust J Exp Biol Med Sci. 1979;57(6):581-582.

33. Cybinski DH. Douglas and Tinaroo viruses: two Simbu group arboviruses infecting Culicoides brevitarsis and livestock in Australia. Aust J Biol Sci. 1984;37(3):91-97.

34. McPhee DA, Parsonson IM, Della-Porta AJ, Jarrett RG. Teratogenicity of Australian Simbu serogroup and some other Bunyaviridae viruses: the embryonated chicken egg as a model. Infect Immun. 1984;43(1): 413-420.

35. Jagoe S, Kirkland PD, Harper PA. An outbreak of Akabane virusinduced abnormalities in calves after agistment in an endemic region. Aust Vet J. 1993;70(2):56-58.

36. Clerx-van Haaster CM, Akashi H, Auperin DD, Bishop DH. Nucleotide sequence analyses and predicted coding of bunyavirus genome RNA species. J Virol. 1982;41(1):119-128.

37. Collett MS, Purchio AF, Keegan K, et al. Complete nucleotide sequence of the M RNA segment of Rift Valley fever virus. Virology. 1985;144(1):228-245.

38. Obijeski JF, McCauley J, Skehel JJ. Nucleotide sequences at the terminal of La Crosse virus RNAs. Nucleic Acids Res. 1980;8(11):2431-2438.

39. Schmaljohn CS, Dalrymple JM. Analysis of Hantaan virus RNA: evidence for a new genus of bunyaviridae. Virology. 1983;131(2): 482-491.

40. Elliott RM, Blakqori G, van Knippenberg I, et al. Establishment of a reverse genetic system for Schmallenberg virus, a newly emerged orthobunyavirus in Europe. J Gen Virol. Epub December 19, 2012.

41. Fontana J, López-Montero N, Elliott RM, Fernández JJ, Risco C. The unique architecture of Bunyamwera virus factories around the Golgi complex. Cell Microbiol. 2008;10(10):2012-2028.
42. Novoa RR, Calderita G, Cabezas P, Elliott RM, Risco C. Key Golgi factors for structural and functional maturation of bunyamwera virus. J Virol. 2005;79(17):10852-10863.

43. Salanueva IJ, Novoa RR, Cabezas P, et al. Polymorphism and structural maturation of bunyamwera virus in Golgi and post-Golgi compartments. J Virol. 2003;77(2):1368-1381.

44. López-Montero N, Risco C. Self-protection and survival of arbovirusinfected mosquito cells. Cell Microbiol. 2011;13(2):300-315.

45. Walter CT, Barr JN. Recent advances in the molecular and cellular biology of bunyaviruses. J Gen Virol. 2011;92(Pt 11):2467-2484.

46. Bupp K, Stillmock K, González-Scarano F. Analysis of the intracellular transport properties of recombinant La Crosse virus glycoproteins. Virology. 1996;220(2):485-490.

47. Lappin DF, Nakitare GW, Palfreyman JW, Elliott RM. Localization of Bunyamwera bunyavirus G1 glycoprotein to the Golgi requires association with G2 but not with NSm. J Gen Virol. 1994;75(Pt 12): 3441-3451.

48. Rönkä H, Hildén P, Von Bonsdorff $\mathrm{CH}$, Kuismanen E. Homodimeric association of the spike glycoproteins $\mathrm{G} 1$ and $\mathrm{G} 2$ of Uukuniemi virus. Virology. 1995;211(1):241-250.

49. Rönnholm R. Localization to the Golgi complex of Uukuniemi virus glycoproteins G1 and G2 expressed from cloned cDNAs. JVirol. 1992; 66(7):4525-4531.

50. Shi X, van Mierlo JT, French A, Elliott RM. Visualizing the replication cycle of bunyamwera orthobunyavirus expressing fluorescent proteintagged Gc glycoprotein. J Virol. 2010;84(17):8460-8469.

51. Bishop DH, Gay ME, Matsuoko Y. Nonviral heterogeneous sequences are present at the $5^{\prime}$ ends of one species of snowshoe hare bunyavirus S complementary RNA. Nucleic Acids Res. 1983;11(18):6409-6418.

52. Garcin D, Lezzi M, Dobbs M, et al. The 5' ends of Hantaan virus (Bunyaviridae) RNAs suggest a prime-and-realign mechanism for the initiation of RNA synthesis. J Virol. 1995;69(9):5754-5762.

53. Patterson JL, Holloway B, Kolakofsky D. La Crosse virions contain a primer-stimulated RNA polymerase and a methylated cap-dependent endonuclease. J Virol. 1984;52(1):215-222.

54. Patterson JL, Kolakofsky D. Characterization of La Crosse virus smallgenome transcripts. J Virol. 1984;49(3):680-685.

55. Simons JF, Pettersson RF. Host-derived $5^{\prime}$ ends and overlapping complementary $3^{\prime}$ ends of the two mRNAs transcribed from the ambisense S segment of Uukuniemi virus. J Virol. 1991;65(9):4741-4748.

56. Reguera J, Weber F, Cusack S. Bunyaviridae RNA polymerases (L-protein) have an N-terminal, influenza-like endonuclease domain, essential for viral cap-dependent transcription. PLoS Pathog. 2010; 6(9):e1001101.

57. Blakqori G, van Knippenberg I, Elliott RM. Bunyamwera orthobunyavirus S-segment untranslated regions mediate poly(A) tail-independent translation. J Virol. 2009;83(8):3637-3646.

58. Mir MA, Panganiban AT. The triplet repeats of the Sin Nombre hantavirus $5^{\prime}$ untranslated region are sufficient in cis for nucleocapsidmediated translation initiation. J Virol. 2010;84(17):8937-8944.

59. Mir MA, Panganiban AT. A protein that replaces the entire cellular eIF4F complex. EMBO J. 2008;27(23):3129-3139.

60. Vera-Otarola J, Soto-Rifo R, Ricci EP, Ohlmann T, Darlix JL, López-Lastra M. The 3' untranslated region of the Andes hantavirus small mRNA functionally replaces the poly(A) tail and stimulates cap-dependent translation initiation from the viral mRNA. J Virol. 2010;84(19):10420-10424.

61. Kalveram B, Lihoradova O, Ikegami T. NSs protein of rift valley fever virus promotes posttranslational downregulation of the TFIIH subunit p62. J Virol. 2011;85(13):6234-6243.

62. Kalveram B, Lihoradova O, Indran SV, Lokugamage N, Head JA, Ikegami T. Rift Valley fever virus NSs inhibits host transcription independently of the degradation of dsRNA-dependent protein kinase PKR. Virology. 2012;435(2):415-424.

63. Léonard VH, Kohl A, Hart TJ, Elliott RM. Interaction of Bunyamwera Orthobunyavirus NSs protein with mediator protein MED8: a mechanism for inhibiting the interferon response. JVirol. 2006;80(19): 9667-9675. 
64. Thomas D, Blakqori G, Wagner V, et al. Inhibition of RNA polymerase II phosphorylation by a viral interferon antagonist. J Biol Chem. 2004; 279(30):31471-31477.

65. van Knippenberg I, Carlton-Smith C, Elliott RM. The N-terminus of Bunyamwera orthobunyavirus NSs protein is essential for interferon antagonism. J Gen Virol. 2010;91(Pt 8):2002-2006.

66. Verbruggen P, Ruf M, Blakqori G, et al. Interferon antagonist NSs of La Crosse virus triggers a DNA damage response-like degradation of transcribing RNA polymerase II. J Biol Chem. 2010;286(5): 3681-3692.

67. Mohamed M, McLees A, Elliott RM. Viruses in the Anopheles A, Anopheles B, and Tete serogroups in the Orthobunyavirus genus (family Bunyaviridae) do not encode an NSs protein. J Virol. 2009;83(15): 7612-7618.

68. Lievaart-Peterson K, Luttikholt SJM, Van den Brom R, Vallema P. Schmallenberg virus infection in small ruminants - first review of the situation and prospects in Northern Europe. Small Ruminant Research. 2012;106(2):71-76.

69. Maclachlan NJ, Guthrie AJ. Re-emergence of bluetongue, African horse sickness, and other orbivirus diseases. Vet Res. 2010;41(6):35.

70. Saegerman C, Berkvens D, Mellor PS. Bluetongue epidemiology in the European Union. Emerg Infect Dis. 2008;14(4):539-544.

71. Wilson AJ, Mellor PS. Bluetongue in Europe: past, present and future. Philos Trans R Soc Lond B Biol Sci. 2009;364(1530):2669-2681.

72. Carpenter S, Lunt HL, Arav D, Venter GJ, Mellor PS. Oral susceptibility to bluetongue virus of Culicoides (Diptera: Ceratopogonidae) from the United Kingdom. J Med Entomol. 2006;43(1):73-78.

73. Bradshaw B, Mooney J, Ross PJ, et al. Schmallenberg virus cases identified in Ireland. Vet Rec. 2012;171(21):540-541.

74. Conraths F, Peters M, Beer M. Schmallenberg virus, a novel orthobunyavirus infection in ruminants in Europe: potential global impact and preventive measures. N Z Vet J. 2013;61(2):63-67.

75. Dominguez M, Hendrikx P, Zientara S, et al. Preliminary estimate of Schmallenberg virus infection impact in sheep flocks - France. Vet Rec. 2012;171(17):426.

76. Elbers AR, Loeffen WL, Quak S, et al. Seroprevalence of Schmallenberg virus antibodies among dairy cattle, The Netherlands, winter 2011-2012. Emerg Infect Dis. 2012;18(7):1065-1071.

77. Garigliany MM, Bayrou C, Kleijnen D, Cassart D, Desmecht D. Schmallenberg virus in domestic cattle, Belgium, 2012. Emerg Infect Dis. 2012;18(9):1512-1514.

78. Kaba J, Czopowicz M, Witkowski L. Schmallenberg virus antibodies detected in Poland. Transbound Emerg Dis. 2013;60(1):1-3.

79. Martinelle L, Dal Pozzo F, Gauthier B, Kirschvink N, Saegerman C. Field veterinary survey on clinical and economic impact of Schmallenberg virus in Belgium. Transbound Emerg Dis. Epub December 24, 2012.

80. Méroc E, De Regge N, Riocreux F, CaijAB, van den Berg T, van der StedeY. Distribution of Schmallenberg virus and seroprevalence in Belgian sheep and goats. Transbound Emerg Dis. Epub January 10, 2013.

81. Méroc E, Poskin A, Van Loo H, et al. Large-scale cross-sectional serological survey of schmallenberg virus in belgian cattle at the end of the first vector season. Transbound Emerg Dis. 2012;60(1):4-8.

82. Saegerman C, Martinelle L, Dal Pozzo F, Kirschvink N. Preliminary survey on the impact of Schmallenberg virus on sheep flocks in south of Belgium. Transbound Emerg Dis. Epub January 7, 2013.

83. Steinbach F, Dastjerdi A, Drew T, Cook A, Davies I. Continued presentation of cases of Schmallenberg virus in sheep in England. Vet Rec. 2012;170(21):547.

84. Kim YH, Kweon CH, Tark DS, et al. Development of inactivated trivalent vaccine for the teratogenic Aino, Akabane and Chuzan viruses. Biologicals. 2011;39(3):152-157.

85. Kurogi H, Inaba Y, Takahashi E, et al. Development of inactivated vaccine for Akabane disease. Natl Inst Anim Health $Q$ (Tokyo). 1978;18(3-4):97-108.
86. Kurogi H, Inaba Y, Takahashi E, et al. An attenuated strain of Akabane virus: a candidate for live virus vaccine. Natl Inst Anim Health $Q$ (Tokyo). 1979;19(1-2):12-22.

87. Varela M, Schnettler E, Caporale M, et al. Schmallenberg virus pathogenesis, tropism and interaction with the innate immune system of the host. PLoS Pathog. 2013;9(1):e1003133.

88. Dungu B, Louw I, Lubisi A, Hunter P, von Teichman BF, Bouloy M. Evaluation of the efficacy and safety of the Rift Valley Fever Clone 13 vaccine in sheep. Vaccine. 2010;28(29):4581-4587.

89. von Teichman B, Engelbrecht A, Zulu G, Dungu B, Pardini A, Bouloy M. Safety and efficacy of Rift Valley fever Smithburn and Clone 13 vaccines in calves. Vaccine. 2011;29(34):5771-5777.

90. González M, López S, Mullens BA, Baldet T, Goldarazena A. A survey of Culicoides developmental sites on a farm in northern Spain, with a brief review of immature habitats of European species. Vet Parasitol. 2012;191(1-2):81-93

91. Ninio C, Augot D, Dufour B, Depaquit J. Emergence of Culicoides obsoletus from indoor and outdoor breeding sites. Vet Parasitol. 2011;183(1-2):125-129.

92. Hendrickx G, Gilbert M, Staubach C, et al. A wind density model to quantify the airborne spread of Culicoides species during north-western Europe bluetongue epidemic, 2006. Prev Vet Med. 2008;87(1-2): $162-181$.

93. Faes C, van der Stede $\mathrm{Y}$, Guis $\mathrm{H}$, et al. Factors affecting Bluetongue serotype 8 spread in Northern Europe in 2006: The geographical epidemiology. Prev Vet Med. Epub December 27, 2012.

94. Vasconcelos HB, Nunes MR, Casseb LM, et al. Molecular epidemiology of Oropouche virus, Brazil. Emerg Infect Dis. 2011;17(5):800-806.

95. Aguilar PV, Barrett AD, Saeed MF, et al. Iquitos virus: a novel reassortant Orthobunyavirus associated with human illness in Peru. PLoS Negl Trop Dis. 2011;5(9):e1315.

96. Barnard BJ. Antibodies against some viruses of domestic animals in southern African wild animals. Onderstepoort J Vet Res. 1997;64(2): 95-110.

97. Cybinski DH, St George TD, Paull NI. Antibodies to Akabane virus in Australia. Aust Vet J. 1978;54(1):1-3.

98. Yang DK, Kim BH, Kweon CH, et al. Serosurveillance for Japanese encephalitis, Akabane, and Aino viruses for thoroughbred horses in Korea. J Vet Sci. 2008;9(4):381-385.

99. Della-Porta AJ, O’Halloran ML, Parsonson IM, et al. Akabane disease: isolation of the virus from naturally infected ovine foetuses. Aust Vet J. 1977;53(1):51-52.

100. Inaba Y, Kurogi H, Omori T. Letter: Akabane disease: epizootic abortion, premature birth, stillbirth and congenital arthrogryposishydranencephaly in cattle, sheep and goats caused by Akabane virus. Aust Vet J. 1975;51(12):584-585.

101. Kurogi H, Inaba Y, Takahashi E, et al. Epizootic congenital arthrogryposis-hydranencephaly syndrome in cattle: isolation of Akabane virus from affected fetuses. Arch Virol. 1976;51(1-2):67-74.

102. Kurogi H, Inaba Y, Takahashi E, Sato K, Satoda K. Congenital abnormalities in newborn calves after inoculation of pregnant cows with Akabane virus. Infect Immun. 1977;17(2):338-343.

103. Oya A, Okuno T, Ogata T, Kobayashii, Matsuyama T. Akabane, a new arbor virus isolated in Japan. Jpn J Med Sci Biol. 1961;14:101-108.

104. Parsonson IM, Della-Porta AB, Snowdon WA, Murray MD. Letter: Congenital abnormalities in foetal lambs after inoculation of pregnant ewes with Akabane virus. Aust Vet J. 1975;51(12):585-586.

105. Parsonson IM, Della-Porta AJ, Snowdon WA. Congenital abnormalities in newborn lambs after infection of pregnant sheep with Akabane virus. Infect Immun. 1977;15(1):254-262.

106. Horikita T, Yoshinaga S, Okatani AT, Yamane I, Honda E, Hayashidani H. Loss of milk yield due to Akabane disease in dairy cows. J Vet Med Sci. 2005;67(3):287-290.

107. Huang CC, Huang TS, Deng MC, Jong MH, Lin SY. Natural infections of pigs with akabane virus. Vet Microbiol. 2003;94(1):1-11. 
108. Kamata H, Inai K, Maeda K, et al. Encephalomyelitis of cattle caused by Akabane virus in southern Japan in 2006. J Comp Pathol. 2009; 140(2-3):187-193.

109. Liao YK, Lu YS, Goto Y, Inaba Y. The isolation of Akabane virus (Iriki strain) from calves in Taiwan. J Basic Microbiol. 1996;36(1): 33-39.

110. Miyazato S, Miura Y, Hase M, Kubo M, Goto Y, Kono Y. Encephalitis of cattle caused by Iriki isolate, a new strain belonging to Akabane virus. Nihon Juigaku Zasshi. 1989;51(1):128-136.

111. Noda Y, Uchinuno Y, Shirakawa H, et al. Aino virus antigen in brain lesions of a naturally aborted bovine fetus. Vet Pathol. 1998;35(5): 409-411.

112. Takahashi K, Oya A, Okazda T, Matsuo R, Kuma M. Aino virus, a new a new member of simbu group of arbovirus from mosquitoes in Japan. Jpn J Med Sci Biol. 1968;21(2):95-101.

113. Uchinuno $Y$, Noda $Y$, Ishibashi $\mathrm{K}$, et al. Isolation of Aino virus from an aborted bovine fetus. J Vet Med Sci. 1998;60(10):1139-1140.

114. Yanase T, Kato T, Kubo T, et al. Isolation of bovine arboviruses from Culicoides biting midges (Diptera: Ceratopogonidae) in southern Japan: 1985-2002. J Med Entomol. 2005;42(1):63-67.

115. Yamakawa M, Yanase T, Kato T, Tsuda T. Molecular epidemiological analyses of the teratogenic Aino virus based on the sequences of a small RNA segment. Vet Microbiol. 2008;129(1-2):40-47.
116. Rodrigues FM, Singh PB, Dandawate CN, Soman RS, Bhatt PN. Kaikalur virus - a new arthropod-borne virus belonging to the Simbu group isolated in India from Culex tritaeniorhynchus (Giles). Indian J Med Res. 1977;66(5):719-725.

117. Anderson CR, Spence L, Downs WG, Aitken TH. Oropouche virus: a new human disease agent from Trinidad, West Indies. Am J Trop Med Hyg. 1961;10:574-578.

118. Azevedo RS, Nunes MR, Chiang JO, et al. Reemergence of Oropouche fever, northern Brazil. Emerg Infect Dis. 2007;13(6):912-915.

119. Gard GP, Shorthose JE, Weir RP, Walsh SJ, Melville LF. Arboviruses recovered from sentinel livestock in northern Australia. Vet Microbiol. 1988;18(2):109-118.

120. Murray MD, Kirkland PD. Bluetongue and Douglas virus activity in New South Wales in 1989: further evidence for long-distance dispersal of the biting midge Culicoides brevitarsis. Aust Vet J. 1995;72(2):56-57.

121. St George TD, Standfast HA, Cybinski DH, Filippich C, Carley JG. Peaton virus: a new Simbu group arbovirus isolated from cattle and Culicoides brevitarsis in Australia. Aust J Biol Sci. 1980;33(2): 235-243.

122. Yanase T, Maeda K, Kato T, et al. The resurgence of Shamonda virus, an African Simbu group virus of the genus Orthobunyavirus, in Japan. Arch Virol. 2005;150(2):361-369.
Virus Adaptation and Treatment

\section{Publish your work in this journal}

Virus Adaptation and Treatment is an international, peer-reviewed open access journal focusing on the study of virology, viral adaptation and the development and use of antiviral drugs and vaccines to achieve improved outcomes in infection control and treatment. The journa welcomes original research, basic science, clinical \& epidemiological

\section{Dovepress}

studies, reviews \& evaluations, expert opinion and commentary, case reports and extended reports. The manuscript management system is completely online and includes a very quick and fair peer-review system, which is all easy to use. Visit http://www.dovepress.com/ testimonials.php to read real quotes from published authors. 